\title{
A Study of the controversial Role of Malala Yousafzai
}

\author{
Nausheen Fatima Jaffri* \\ Raana Afzal**
}

\begin{abstract}
The name of Malala Yousafzai is household is bestowed with many honors and the greatest of all is the Nobel Prize for peace. Her role as teenage girl presented for efforts against Taliban that she played for girls' education who prohibited their right. Through this article, it will be analyze that whether her role is politicize for specific reasons or she has genuinely worked for her cause. Education is compulsory for every human being whether man or woman and government of Pakistan acknowledges such right. The article 25-A of the constitution of Pakistan states, 'the state shall provide free and compulsory education to all children from the age of five to sixteen in such manner as may be determined by law'. The government of Pakistan seems responsive towards its constitutional obligation. Hence, a certain section of Pakistani society disapprove her due to her association with west while another segment supports her efforts. Since the creation of Pakistan, several philanthropists have spent their lives for the betterment of their nation and their work has become identity of Pakistan in abroad so, why Malala decided to leave Pakistan? It is the question emerge in mind of every Pakistani and sometimes it is believe that her entire humanitarian works is a stage show. As far as female education is concerned, it is a comprehensive term in Pakistani society and a specific class use it as a political gain otherwise the overall conditions of women in Pakistan are not bad.
\end{abstract}

Key Words: Pakistan, education, Islam, west, terrorism

*Research Scholar, Department of Political Science, University of Karachi

** Lecturer, Department of Mass Communication, University of Karachi 


\section{Research Methodology}

The research methodology is the major part of a research work, its adaptation is important in various senses but two are very important, one is that the researcher does not derail from his/ her line of work secondly and the people would easily understand the answers which would be find out by the researcher. There are mainly two main branches of research methodology: the quantitative methods and the qualitative methods.

The quantitative methods are about numbers whereas; the qualitative methods generally aim to understand the experiences and attitudes. These methods aim to answer questions about the what, how or why of a phenomenon rather than how many or how much, which are answered by quantitative methods. ${ }^{1}$ The branch of methodology used in this research paper is the qualitative research with the view to obtain maximum opportunity to discuss the topic as; the Malala Yousafzai is not an individual's story, but a subject that has various dimensions.

\section{Introduction}

It is a fact that since 9/11, the political situation of Pakistan has taken a turn and it has to fight as advance guard in war on Terror because it fears an unstable Afghanistan that becomes a safe-haven for anti-Pakistan militant groups and a dangerous playground for outside powers, even though this has already happened. ${ }^{2}$ Pakistan keeps an important geo-strategic position in the world such position has ever produced long-lasting impact on its political, social and economic conditions. The world community always needs its political and military strategic assistance similarly during the war on Terror Pakistan played pivotal role. The war against terrorism that began in 2001 with the attacks on Twin Towers, Manhattan, NY, USA actually been fought in Pakistan. It was the demand of time that Pakistan put its share in international campaign against terrorism. Definitely, the consequences of that role remained severe and Pakistan has to face them at vast level.

Whenever, the role of Pakistan in war against terrorism is discuss the problems it confronted during that period will also be explain. The Pakistan not only became the place of warfare and received every impact of war directly or indirectly. Terrorism, can be considered the universal human phobia and Pakistan always wants to save

1 Patton, Quinn \& Patton. Medicines. The Guide to Using Qualitative Research Methodology. Sage Publication, 2002.p. 3

2 Order from chaos. Why Pakistan supports terrorist groups and why the US finds it so hard to induce change. 2016. Retrieved from http://www.terrorist-groups-and -whythe-us- finds -it- so- hard- to- induce- change. 
its nation from every fear hence the decision to play the role in international war on terror was the necessity of that time. Firstly, the economy had struck hence the other competitive nations got chance to move rapidly. The graph 1 and2, represent the economic conditions of Pakistan since independence until 2008 that how its economy disturbed.
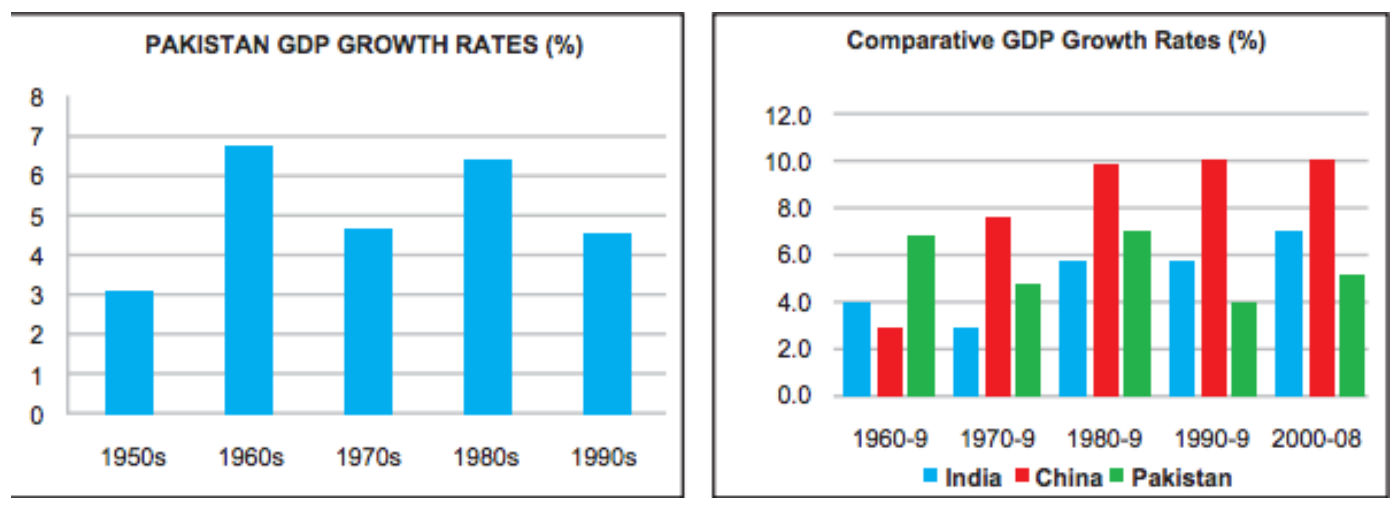

\section{Graph $1 \& 2$}

When the economic and political conditions are instable, they cause social impact and the episode of Malala Yousafzai is a part of that social disturbance. Therefore, a certain group disapproves Malala, as it believes that her act is taking advantage of the situation. Unfortunately, the direct action of Pakistan against terrorism provided life to terrorists in Pakistan hence; they commenced their unlawful activities within the borders of Pakistan. These activities were not only against the government machinery, army but also the civilians were targeted especially the western province of Khyber Pakhtunkhwa (N.W.F.P) was severely affected.

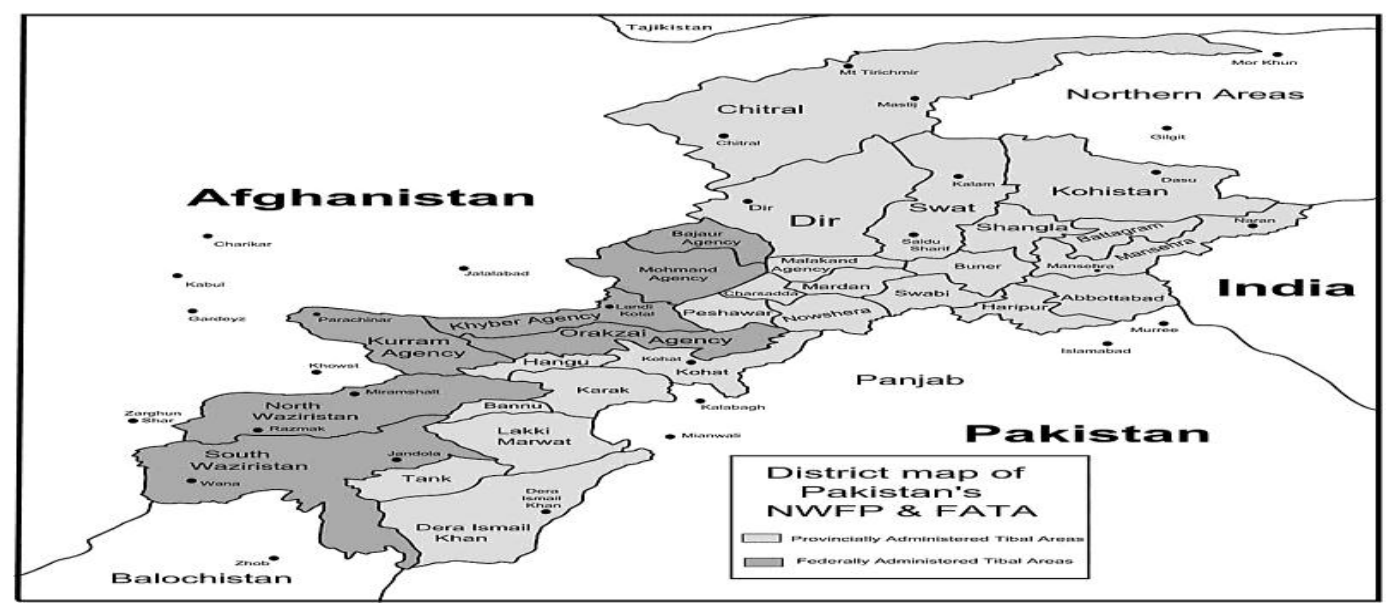

Figure: 01

The figure1 shows, the areas of Khyber Pakhtunkhwa affected by militants. 
During the Taliban insurgency, militant captured Swat, who tried to impose restrictions on local public. Such unlawful elements did not have support from public therefore; they endeavored to terrorize them through illegal tactics. In response to the situation, the Pakistan security forces initiated the operation Rah-iHaq in 2009 with the moto of "shoot-on-sight "in the densely populated cities of Swat. Militants, as a result attacked security forces and destroyed girls' schools ${ }^{3}$. The world history is evident that enemies attack schools and hospitals similarly; the militants did to create malaise in people.

The group that calls Malala a sham believes that the foreign media has been instrumental to Malala story that her father uses her name to cash the situation; it presented a good image of Pakistan at international level that benefitted Malala and her family only.

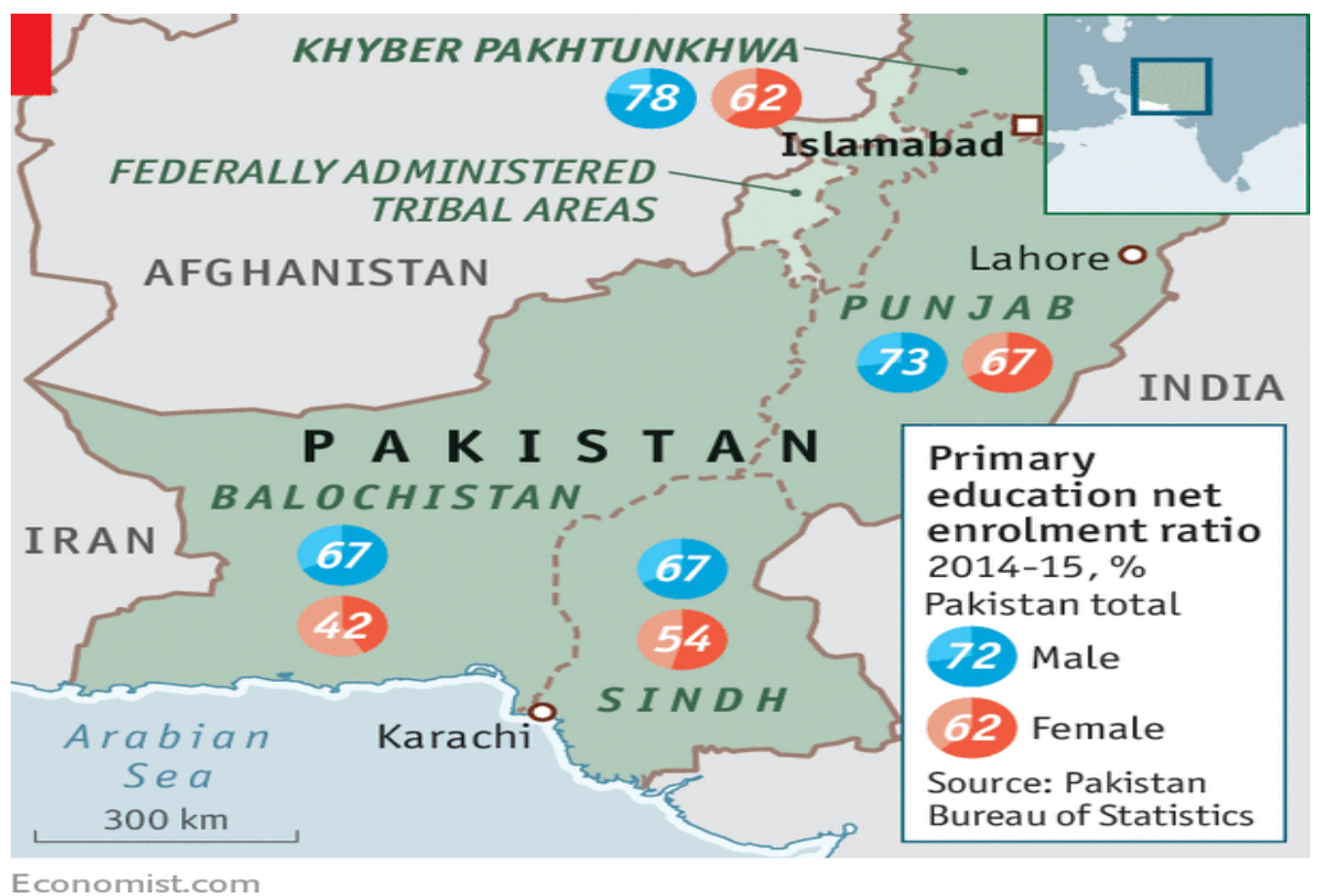

Figure: 02

The above figure shows the net enrolment ratio at primary level during the period 2014-15. It seems very impressive that the ratio of both genders does not have

3 Khalid, Iram. Operation Rah-i-Haq III, Pakistan's Military Operations: Counter Terrorism strategy (2001-2013) Prospects and Implications. JRSP. 2016, Vol. 53, No.2 
major difference, it was in this period when Pakistan was engaged in war on terror, and the attack on Army Public School had already happened.

While the other group believes, that Malala has helped to gain international attention towards the serious issue of schools' attack in Pakistan and opened up new doors. Undoubtedly, the knowledge and empowerment of one woman can bring about a change in a family and in the society as a whole. This change can take place when the woman is educated. Women are the real constructors of nation. It is a truth that behind the success of every nation it is the education of women while the education plays a pivotal role in developing and under-developed countries. In today's civilized world, education is a human right.

The Article 37 of the Constitution of Pakistan stipulates education as the fundamental right of every citizen but unfortunately, still gender discrepancies exist regarding education in Pakistani society. These people believe that the successive governments have announced various programs but they remained failed to bring their words into actions because of political, cultural and social obstacles. The patriarchal values like in Pakistan where the women is consider as the code of honor and four walls of home are defined their space to play their productive role as mother or wife, Malala formed an image of female courage that can bring changes in society.

\section{Reality of the situation}

There is no doubt that Pakistan is a feudal country and the role of male members in family is dominating such system is inherited by the British Empire. Now, the things have been complicated that in Pakistan, the feudal known as Chaudharies, Warraich, Pirs, Mirzas, Khars, Legharis, Nawabzadas, Nawabs, Sardars and Shahs. ${ }^{4}$ These feudals keep influential position in their areas and no province of Pakistan is immune to feudalism whether it exists in the form of zaminadars, tribal chiefs or Pirs $^{5}$. In such situation, the influence of these feudal are so deep that it is like state within state. This creates social issues and NGO and foreign media take interest. It seems that the Malala case is, put in the picture to gain political attention of the world. Critics alleged her for establishing western supremacy to set out malign Pakistan and Islam especially after her autobiography was publish. The book - I Am Malala- made her more controversial as she became a tool in the hands of the western powers. In her book, she explain the impuissance of her that manipulates the reality of the situation. She also state that Pakistan has never shown any weakness in front of militants. Her book has been banned Pakistani educational institutions.

4 Javaid, Umbreen, Aslam \& Tahmina. Feudalism in Pakistan: Myth or Reality/Challenges to feudalism. Journal of the Research Society of Pakistan. 2017, p. 228

5 Ibid., 
In Pakistan, feudalism is recognize by its certain facts ranging from the oppression of women to the oppression of the peasantry ${ }^{6}$ but it does not mean that women's rights are suppressed and no factor could ever retain them. The government machinery and constitution protect all religious and ethical rights of women hence, the Malala story seems to be far from reality and critiques presume that she has been working on foreign agenda.

Her intentions are not social but she has political aims as Malala has herself said in an interview to BBC that, "I will be a politician in my future. I want to change the future of my country and I want to make education compulsory". Such words support those who criticize her and raise questions that she has maligned the Islam and her country otherwise the overall political and social conditions of Pakistan are not bad. They are of the view that a sense of awareness has always been existed in nation therefore, a woman has served as Prime Minister and several women have served or have been serving at responsible positions. However, women's political participation and protection of women's right has always been a challenge in developing countries. Despite that fact that Pakistan is a developing country with a developing economy yet women have actively been attempting to take part in government and female- oriented civil society ${ }^{7}$ even women possess participation in legislation through female quota as well. Hence, it is ill perception that women are restricted to play their role in politics, economy and other sectors. In Malala's own hometown, Swat the Women Chambers of Commerce and Industries founded with the aim to encourage women as entrepreneurs. Therefore, the perception formed by western powers that Pakistan is backward society for women is false.

\title{
What makes Malala controversial figure?
}

Malala is an intelligent girl who has been trying to play the role of a human rights activist but her continuous efforts to prove herself a political scientist have made her a controversial figure. She has expressed her political thoughts in such words, "I am convinced that socialism is the only answer and I urge all comrades to struggle to a victorious conclusion. Only this will free us from the chain of bigotry and exploitation". ${ }^{8}$ It is a clear-cut opinion, but people view, it affirms that she disagrees the ideology of Pakistan and makes her a controversial personality.

The founder of Pakistan Quaid-e-Azam Muhammad Ali Jinnah has said, no nation can raise to the height of glory unless your women are side by side with you. It does not mean that we should imitate the western life. However, let us try to raise the

\author{
Ibid., \\ Elashi, Noran. Women's Political Participation in Pakistan. 2014 \\ Yousafzai, Malala. Quotes. Retrieved from http://www.goodreads.com/...7597965, 2016
}


status of our women according to our own Islamic ideas and standards ${ }^{9}$. People who oppose her, opines two reasons for not accepting her views; firstly, Pakistan is an Islamic democratic state that does not follow any other system of governance while these thoughts are because of immaturity or less- knowledge. Secondly, her ideology has opened the new doors for political analysts that it will take the establishment of not just bourgeois political democracy, but of economic democracy of socialism. ${ }^{10}$

Another view is that Malala has herself created a difficult situation for her; sometimes she seems to be over- influenced by west. In their view Pakistani women is given respect for her dignity, civilization and religion that cannot be called barriers at all. The western media has always tried to show the goad image of Muslim community similarly, it has done in the case of Malala. Through, such cases western media justifies the attack on Afghanistan by western forces as; in figure 1, it clearly show that Khyber Pakhtunkhwa province is the adjacent area of Afghanistan. During Afghan attack, hundreds of innocent people lost their lives in drone strikes.

\section{Conclusion:}

Malala Yousafzai is a confident and cultured girl who hails from a rural area of Pakistan. She has awarded with several honors and the greatest of them is Noble Prize but she is consider a controversial personality in Pakistan. It may be because the west has spoilt her, the overwhelming attention by foreign media tried to make role model for Pakistani women. Such approach destroyed her and she started to compare the societies sometimes, it seems that she is very much impressed by the west and she had spent a depressed life in Pakistan like once she said, "I do not know why people have divided the whole world into two groups: east and west. I do not know what the difference between east and west is." That could be her own thinking but foreign media gave it extra-ordinary coverage that created predicament for her. There is yet another perception that she likes to be in limelight through her controversial statements.

9 Butt, Ghazala. 2016. Jinnah's Concept of an Ideal Muslim Women. Retrieved from www.bzu.edu.pk/PJIR/eng6, 2016

10 Norton, Ben. 2016. The Malala you won't hear about. Retrieved from

SocialistWorker.org. 2016 
Jhss, Vol. 9, No. 2 , July to December, 2018

\section{References}

Butt, Ghazala. Jinnah's Concept of an Ideal Muslim Women. Retrieved from www.bzu.edu.pk/PJIR/eng6, 2016

Norton, Ben. The Malala you will not hear about. Retrieved from SocialistWorker.org. 2016

Order from chaos. Why Pakistan supports terrorist groups and why the US finds it so hard to induce change. 2016. Retrieved from http://www.terrorist-groups-and why-the-us- finds -it- so- hard- to- induce- change.

Yousafzai, Malala. Quotes. Retrieved from http://www.goodreads.com/...7597965, 2016

Elashi, Noran. Women's Political Participation in Pakistan. 2014

Javaid, Umbreen, Aslam \& Tahmina. Feudalism in Pakistan: Myth or

Reality/Challenges to feudalism. Journal of the Research Society of Pakistan. 2017

Khalid, Iram. Operation Rah-i-Haq III, Pakistan's Military Operations: Counter Terrorism strategy (2001-2013) Prospects and Implications. JRSP. 2016, Vol. 53, No.2

Patton, Quinn \& Patton. Medicines. The Guide to Using Qualitative Research Methodology. Sage Publication. 2002 